\title{
Bringing About Marked Increases in Freshman Engineering Retention
}

\author{
John T. Demel, Robert J. Gustafson, Audeen W. Fentiman, Richard J. Freuler, \\ and John A. Merrill \\ College of Engineering \\ The Ohio State University
}

\begin{abstract}
During the past ten years, The Ohio State University's College of Engineering has moved from a series of separate freshman courses for engineering orientation, engineering graphics, and engineering problem solving with computer programming to a dual offering of integrated course sequences in the Introduction to Engineering Program (IEP) and the Freshman Engineering Honors (FEH) Program. These new programs retain part of the traditional material but add in hands-on laboratory experiences that lead to reverse engineering and design/build projects. The relational practices - teamwork and project management, along with report writing and oral presentations and ethics have assumed important roles in this program. The programs are designed to have faculty from all of the degree granting departments teach freshmen. These programs were developed to improve the retention and early decision to stay or leave for new freshmen and to lay a foundation to better address some of the ABET 2000 accreditation criteria. Retention has improved markedly. This paper provides a brief description of the freshman programs, a summary of changes accomplished, and the retention statistics for the College of Engineering.
\end{abstract}

\section{Introduction}

In 1988, at The Ohio State University the retention of engineering students to the junior year ranged between 40 and 50 percent. See Figure 1 . This followed the national norms. In the early 1990's the Ohio State College of Engineering became part of the NSF funded Gateway Engineering Education Coalition. The other members of the Coalition were Drexel University, Columbia University, Cooper Union, New Jersey Institute of Technology, University of Pennsylvania, University of South Carolina, and Florida International University. One focus of the Coalition's efforts was to improve retention to the junior year by using Drexel's integrated E4 curriculum ${ }^{1}$ as a model to be adapted for use in the other Coalition schools. This paper describes the key components of that adaptation and how they have affected retention at Ohio State University. There are four papers in the ASEE 2001 Annual Conference Proceedings ${ }^{2,3,4,5}$ that describe the components of Ohio State's First Year Engineering Programs in some detail. 
Figure 1. Retention of 1988 New First Quarter Freshman

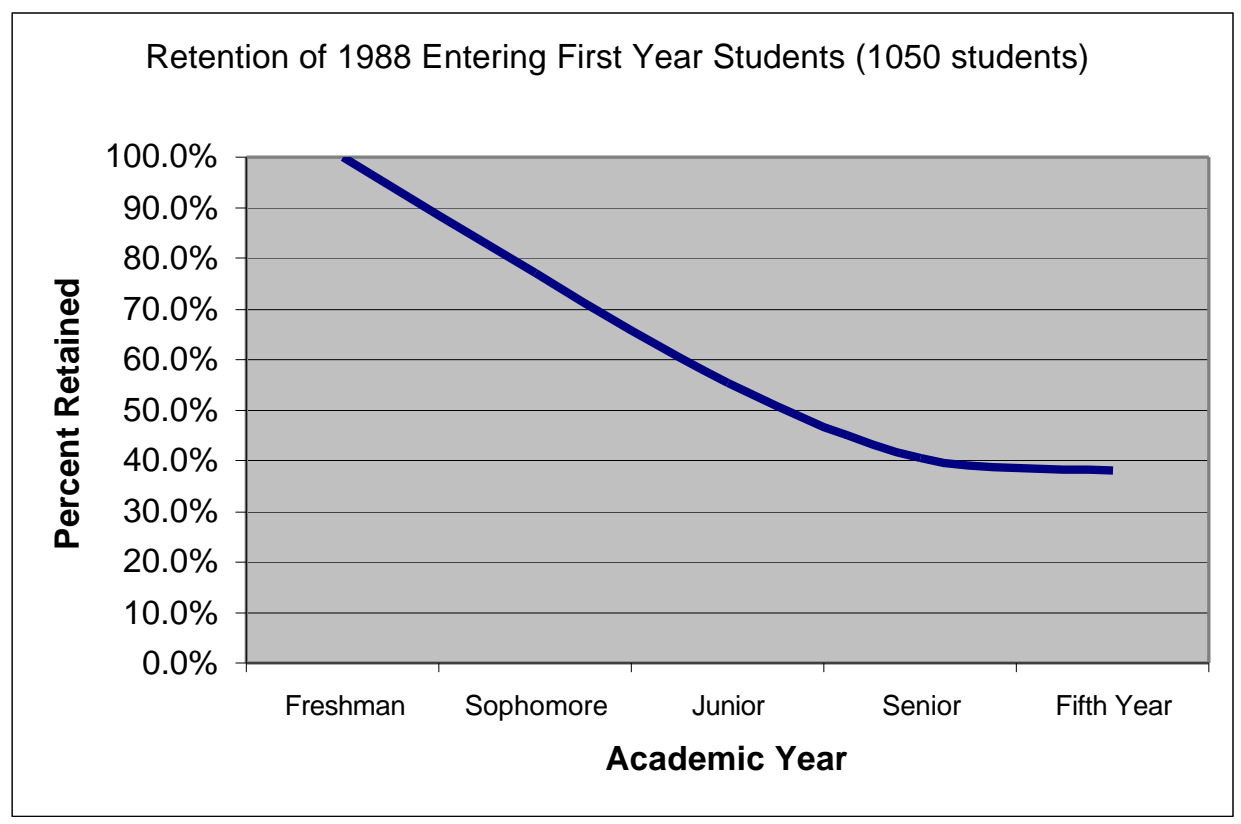

\section{The Freshman Engineering Programs}

Ohio State has two programs for their first year engineering students. The first one is the First Year Engineering Honors (FEH) program. Students designated Honors by the University can opt for the FEH program. The second one is the Introduction to Engineering Program (IEP) that is required of all students as of Autumn 2001The FEH Program is a sequence of three courses of four credits each. The first course (Autumn Quarter) covers Engineering Graphics and CADD. It also has eight hands-on labs and one two-person design project. The second course (Winter Quarter) is primarily a programming course and covers $\mathrm{C}$ with a little $\mathrm{C}++$ and MATLAB. This course has eight more hands-on labs. These 16 hands-on labs cover the various disciplines in the College of Engineering. The third course (Spring Quarter) is a ten-week team design-buildcompete-document project. Most of the student teams design and build small autonomous robots that have to perform a given series of tasks. The classrooms used for these courses are technology enhanced such that each student has access to a computer and collaborative learning is facilitated ${ }^{4}$. In the classroom portion of the course, each faculty member has two undergraduate Peer Mentors (teaching assistants) who help when the students are working on daily assignments do much of the grading. When the students go to the hands-on labs, the teaching team consists of the faculty member, a graduate teaching (GTA) and two undergraduate teaching associates. The class size is limited to 36. The students work in teams of two or four depending on the assignment. In 2001-2002, there were seven sections (252 students) of this course sequence. The sequence began in 1993 as part of the Gateway Engineering Education Coalition efforts at Ohio State.

The Introduction to Engineering Program (IEP) is a two-course sequence (three credits each) that is a derivative of the FEH program. Included in the first course are Engineering Graphics and 
CADD. There are nine hands-on labs, which include a model bridge design project. The second course continues the instruction in CADD and Engineering Graphics and teaches an introduction to MATLAB. The focus for the ten lab periods is a team design-build-document project where the product has to meet written performance specifications. The documenting portion for both the IEP and FEH programs includes progress reports, drafts and a final version of a written project report, and an oral presentation. The classroom portion (72 students) has a teaching team of one faculty member, two graduate teaching associates, and two Peer Mentors (undergraduate teaching associates). When these students go to the hands-on labs, the class of 72 is split in half. In each lab room are one faculty member, one GTA, and one Peer mentor to work with nine teams of four students each. In 2001-2002, there were eight sections of 72 students of the first course during Autumn Quarter and sections of the first course and sections of the second course in Winter Quarter. Nine sections of the second course are planned for Spring Quarter 2002.

\section{Program Components}

The programs were developed to incorporate features that had improved retention in other programs or at Ohio State. There were no new features or components added that had not been used before. It is believed by these authors that the combination of components provides the students with motivation, information, an opportunity to get to know their classmates through teamwork, skills that they will need for their careers (and help meet ABET 2000 guidelines), information about the various disciplines, a chance to be creative, and, most importantly, that the College through its personnel care about them and want to help them to succeed. They feel that they are part of the College from the beginning.

\section{Putting Engineering Up Front}

Prior to the 1990s, many engineering programs had mathematics and science up front rather than engineering. The students viewed courses that covered these subjects as barriers to get into engineering. The Drexel E4 program put the emphasis on engineering - hands-on labs and design up front - and the Ohio State development work has focused on doing this as well. From the description given in the section above, it is obvious that these are a key component of the First Year Engineering programs at Ohio State. Weekly and end of term assessment for both the FEH and IEP programs show that the hands-on labs and the design projects are very important to the students' attitudes about learning engineering. Many of the Honors students make the decision to attend Ohio State because of the robot project.

Teaching Engineering Tools for Co-op, Internships, and Upper Division Classes The First Year Engineering Programs are focused on introducing the students to engineering, to the engineering disciplines, and preparing the students for work in industry and for their upper division classes. On the latter point, the students learn Engineering Graphics, CADD, MATLAB, programming, how to take measurements in a laboratory environment, how to write lab reports, how to plan, manage and document a design project and how to work on teams. The reasons (ABET and sound preparation for their careers) for covering these topics are explained to the students and help motivate them to do well.

Proceedings of the 2002 American Society for Engineering Education Annual Conference \& Exposition Copyright $($ 2002, American Society for Engineering Education 
Mentoring

Mentoring has been proven to help retention by providing students with individuals who have experience and knowledge about studying engineering ${ }^{6}$. Undergraduate and graduate students working as teaching associates (TAs) provide peer mentoring for the first year students. These students work with the students during class and labs on a one-to-one basis and gain the students' confidence so that they will ask questions and seek advice. The faculty members from across the College get to meet the students early in their program of study. Learning names and getting to know the students is a key task for these faculty members so that they, like the TAs gain the students' confidence.

\section{Teamwork}

Teams are used during the classroom periods, in the hands-on labs, and in the design projects. Some teams change weekly, some change twice a quarter, and those for the ten-week design projects are constant for the entire project. Instruction on effective teamwork is provided for the students. The book Project Management and Teamwork ${ }^{7}$ is one of the books required for the course. Teamwork is important for helping the students know their classmates. Anecdotal evidence from upper division students shows that the friendships and teamwork with these friends extends into the Junior and Senior years. For some of those students, the friendships continue into the workplace after graduation.

Faculty and Teaching Associates Selection

All of the faculty members are volunteers. The faculty members are recruited by the First Year Engineering Programs. Communication skill, the ability to motivate the students through their enthusiasm for their field, and the willingness to work on a team are all desired characteristics. When they volunteer, the College on a release time basis pays them from their departments in the same way that they are paid on a release time basis for doing research.

Graduate and undergraduate teaching associates (Peer Mentors) are recruited by posting notices around the College and working with the advisors. When the students apply they turn a letter of application and a resume. The applicants are chosen to be interviewed based on their letters and resumes. During the interview process, the staff look for good communications skills (verbal and written), a sincere interest in working with the students to help them succeed, a solid technical background with expertise in engineering graphics and CADD, MATLAB and programming, and hands-on laboratory experience. The faculty members and teaching associates must be willing to come to education workshops to learn more about teaching and learning.

Faculty and Teaching Associate Training and Communications

The First Year Engineering Program staff and faculty provide a four-day workshop for new graduate teaching associates and peer mentors and a two-day workshop for the faculty. The topics covered include cognitive development, learning styles, new teaching methodologies, how to use the technology in the classrooms, and the course material including tutorials in using the CADD package, MATLAB, and the lab exercises. There is a strong emphasis on how students

Proceedings of the 2002 American Society for Engineering Education Annual Conference \& Exposition Copyright $($ 2002, American Society for Engineering Education 
learn and how much they can learn rather than how much material can be presented. In addition to the workshops given prior to Autumn and Winter Quarters, there are weekly meetings of the faculty and graduate students for each course. These meetings are to discuss problems that arise, to designate which members on the teaching team are going to develop test questions, review test questions, and set the criteria for grading. In addition, when a faculty member develops an exam question and its solution, that faculty member grades that problem for all of the students in all of the sections of the course. This ensures that the students are being treated fairly.

\section{Program Materials}

The College faculty members develop the materials for these courses and the program staff refines the materials and mass produce the materials for the students and faculty members. A common syllabus is used for these multiple section courses. Daily exercises, laboratory exercises, design projects, and exams are done in common. A considerable amount of time is spent making sure that all of the instructional materials have been tested and are presented in a professional way. Teachers' lecture notes are provided for the students in course packets and are also available on the Web.

\section{Assessment including Weekly Electronic Journals}

Assessment was built in from the beginning for these two programs. There are end of the quarter assessment instruments for the faculty teaching and for the programs' content and materials. There are also weekly (FEH) or bi-weekly (IEP) anonymous electronic journals so that there is continuous feedback from the students during the quarter ${ }^{8}$. Each faculty member gets her/his students' journal entries. Questions are posed for the students to answer that deal with various aspects of the program. They are told that they can write about things that are not working well (in their opinion) but they cannot just complain. They have to propose a solution to their perceived problem. The faculty members review the summaries of the journals for the sections that they are teaching. They go over the summaries with their students so that the students know that their feedback is being considered. When students address problems that can be resolved immediately, the faculty member tells the students what is going to be changed. If a solution must wait until the next time the course is taught this is also related to the students. At the end of the quarter the results are viewed by the First Year Program faculty and staff and are shared with the teaching team members. The results of assessment are used for continuous program improvement. The students' participation in the program improvement is important in making them feel part of the College.

\section{Summary}

The components discussed above are all ones that have proven to increase retention in one program or another. They include engineering up front, hands-on labs, design projects, teamwork, mentoring, use of regular faculty from a variety of engineering departments, careful selection of graduate teaching assistants, careful selection of undergraduate teaching assistants (peer mentors), faculty and teaching assistant educational workshops, weekly faculty meetings, quality lecture, laboratory, and daily exercise materials, real time feedback through electronic journals, and end of the quarter student evaluation of instruction and program content. From the

Proceedings of the 2002 American Society for Engineering Education Annual Conference \& Exposition Copyright (c) 2002, American Society for Engineering Education 
journals and end of quarter course assessment we know that students like the hands-on labs and design projects. We believe that these activities provide a balance for the more theoretical mathematics courses that they are taking. Students also comment that they like the personable teaching associates and faculty. They like having the journals as a way for them to provide feedback. We also know from the journals that the physical arrangement in the new classrooms and laboratories (four students face-to-face per table provides more opportunities for interaction and the students have reported that they know more people. The net result is that they feel like they belong to the College and they have a peer group of friends.

\section{A summary of the end of course evaluations from the Autumn Quarter are shown below:}

Without a doubt, the students' most favorable experience was participating in the ice cream lab. Students commented favorably on seeing the results from their work and "being rewarded with good ice cream for thorough evaluation and calculation". Many students really had fun with this lab while they learned. Next to eating the ice cream, the most popular part of the lab was figuring out the equation for the mixture and seeing real results from these equations. According to the students, this lab was a hit!

Among other favorites this quarter were the bridge building lab, teamwork, and the field trip to Baker Systems. The bridge building lab created unity between team members giving them a chance to bond as a group. This was a lab that the students were genuinely proud of and enjoyed working together. The students enjoyed the creative outlet they had in this project and enjoyed the competition. The teamwork aspect of this course forced the students to meet new people and improve their communication and teamwork skills. They learned from other members of their group, by helping others, and by being helped themselves. One student commented "The best experience I had in engineering was simply working with my team and using them as resources to understanding the material. Getting to know the members of my group was the most favorable experience." Finally, many students agreed that the field trip to Baker Systems (to see the manufacturing equipment in action) was extremely valuable. This gave students to opportunity to observe real life experiences that exposed them to all types of engineering. Students felt that it put what engineers do into perspective.

Less frequently mentioned, but still popular were using CADD, the Engineering Expo - a recruiting fair (the students were required to attend, observe, and participate, and learning more about computers. Some students enjoyed CADKEY because they felt they had a good understanding of it and preferred it over hand drawings. The Engineering Expo provided students with much appreciated real life experience. One student commented that "I didn't know that much about programs and spreadsheets so this class helped out a lot." Another specific comment was "I liked learning something new each day" while another student commented "the class was well organized."

What the students don't say in specific words is that they feel that they are part of the college, that the teaching staff care about them as individuals and want to help them succeed, and that they have been exposed to real life experiences both in the class and lab. Students are now able to either commit to engineering or make a well-informed decision on choosing another field of study.

\section{Results}

The retention results of these programs are shown in the Table 1 below and also in Figure 2. IEP is the Introduction to Engineering Program that is required of all engineering students. It was piloted first in 1998-99. FEH is the First Year Engineering Honors Program and it was started in 1993 with $\sim 30$ students. The retention in the FEH program has been reasonably good since the program began but only the most recent data in which the program has grown to more than 100 students participating is included.

Proceedings of the 2002 American Society for Engineering Education Annual Conference \& Exposition Copyright $\left({ }^{\circ}\right.$ 2002, American Society for Engineering Education 
Table 1. Retention Data for the First Year Engineering Programs at Ohio State

\begin{tabular}{|c|c|c|c|c|c|c|c|c|c|c|}
\hline & First $\mathrm{Yr}$ & $\%$ & Soph & $\%$ & Junior & $\%$ & Senior & $\%$ & $\begin{array}{l}\text { Fifth } \\
\text { Year }\end{array}$ & $\%$ \\
\hline 1988 Base Line Data & 1050 & $100.0 \%$ & 810 & $77.0 \%$ & 580 & $55.0 \%$ & 425 & $42.1 \%$ & 400 & $38.1 \%$ \\
\hline 1998-1999 IE Pilot & 106 & $100.0 \%$ & 86 & $81.3 \%$ & 64 & $60.4 \%$ & 55 & $51.9 \%$ & & \\
\hline 1998-1999 IE Control & 180 & $100.0 \%$ & 146 & $81.1 \%$ & 104 & $57.8 \%$ & 95 & $52.8 \%$ & & \\
\hline 1998-1999 FEH Pilot & 105 & $100.0 \%$ & 96 & $91.4 \%$ & 82 & $78.1 \%$ & 77 & $73.3 \%$ & & \\
\hline 1998-1999 FEH Control & 105 & $100.0 \%$ & 89 & $84.8 \%$ & 77 & $73.3 \%$ & 64 & $61.0 \%$ & & \\
\hline 1999-2000 IE Pilot & 275 & $100.0 \%$ & 250 & $90.9 \%$ & 197 & $71.6 \%$ & & $0.0 \%$ & & \\
\hline 1999-2000 IE Control & 120 & $100.0 \%$ & 109 & $90.8 \%$ & 72 & $60.0 \%$ & & $0.0 \%$ & & \\
\hline 1999-2000 FEH Pilot & 173 & $100.0 \%$ & 153 & $88.4 \%$ & 145 & $83.8 \%$ & & $0.0 \%$ & & \\
\hline 1999-2000 FEH Control & 60 & $100.0 \%$ & 53 & $88.3 \%$ & 45 & $75.0 \%$ & & $0.0 \%$ & & \\
\hline 2000-2001 IE & 681 & $100.0 \%$ & 535 & $78.6 \%$ & & $0.0 \%$ & & $0.0 \%$ & & \\
\hline 2000-2001 FEH & 218 & $100.0 \%$ & 210 & $96.3 \%$ & & $0.0 \%$ & & $0.0 \%$ & & \\
\hline
\end{tabular}

Figure 2. Combined data for the IE and FEH Programs 1998 - 2000

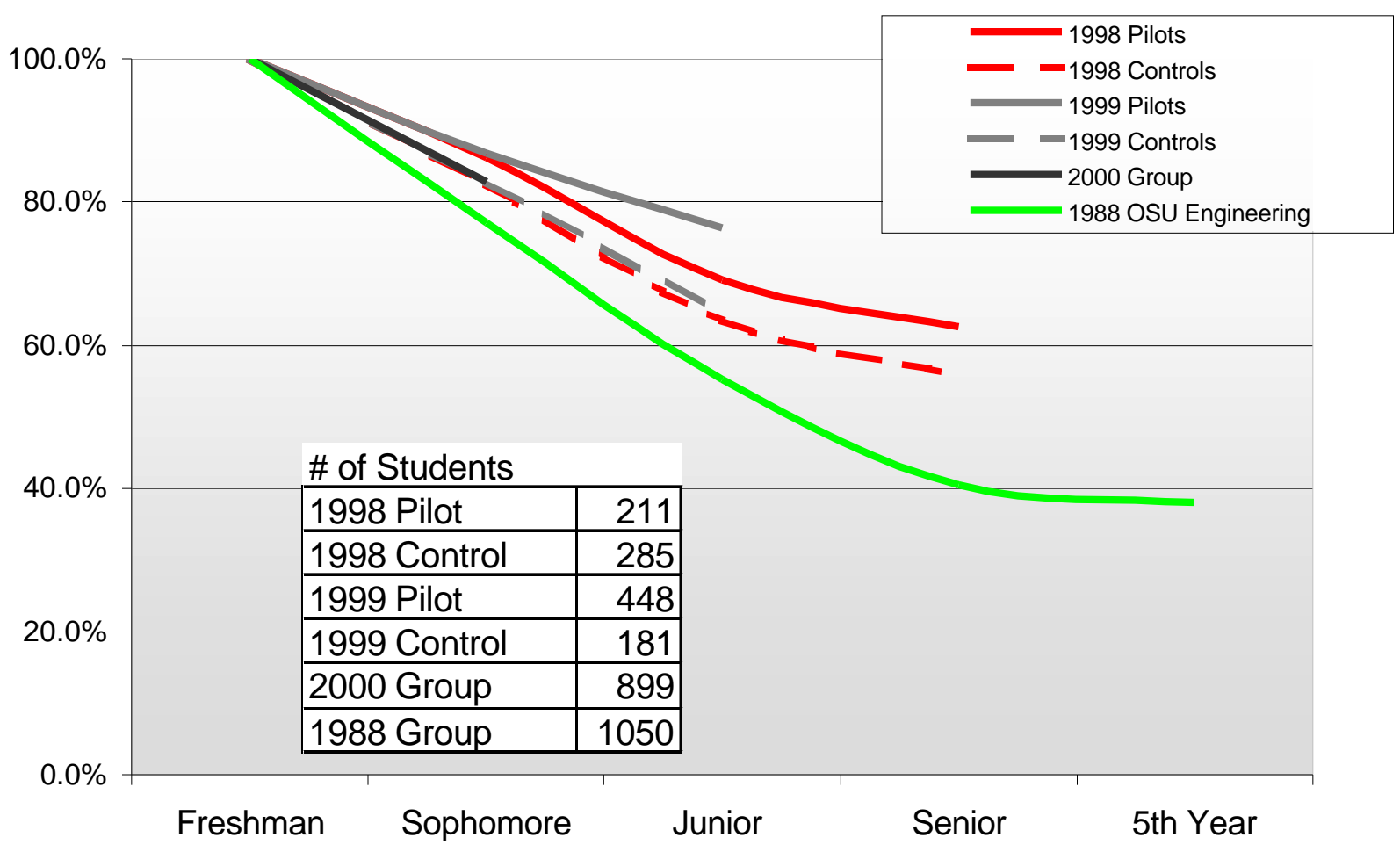

Proceedings of the 2002 American Society for Engineering Education Annual Conference \& Exposition Copyright (C) 2002, American Society for Engineering Education 


\section{Conclusions}

Systematically exploring educational practices that improve retention and then integrating them into the planning and implementation of a set of new courses has worked well at Ohio State. It would be difficult to pick out which one of the processes or educational practices has been the most effective. In the opinion of the authors, it is consistent regard for the students as individuals as shown to them through the personal interactions provided by these programs that is the key to our success. Providing hands-on experiences in class and in the lab are also very important. Our advice to other faculty seeking to improve retention would be to start with a clean slate and design the new practices and processes in from the beginning. Key features of the success of these programs are getting the faculty to agree that improving retention is important and getting the faculty input and approval for the new program design. In an article from EDUCAUSE Review", Donald Buckley concludes "Higher education has entered a transition from the Instructional Paradigm to the Learning Paradigm." The se two First Year Engineering programs are helping Ohio State make this transition.

\section{Bibliography}

1. Fromm, E. and R.G. Quinn, "An Experiment to Enhance the Educational Experience of Engineering Students”, Engineering Education, pp. 424-429, April 1989.

2. Fentiman, A.W., Demel, J.T., Freuler, R.J. Gustafson, R.J., and Merrill, J.A., "Developing and Implementing an Innovative First Year Program for 1000 Students", Proceedings of the 2001 American Society for Engineering Education Annual Conference, June 2001.

3. Freuler, R.J. Fentiman, A.W., Demel, J.T., Gustafson, R.J., and Merrill, J.A., "Developing and Implementing Hands-on Laboratory Exercises and Design Projects for First Year Engineering Students", Proceedings of the 2001 American Society for Engineering Education Annual Conference, June 2001.

4. Gustafson, R.J., Merrill, J.A., Fentiman, A.W., Freuler, R.J., and Demel, J.T., "Developing and Implementing a Facilities Plan for a Freshman Engineering Courses Sequence", Proceedings of the 2001 American Society for Engineering Education Annual Conference, June 2001.

5. Merrill, J.A., Freuler, R.J., Gustafson, R.J. Fentiman, A.W., and Demel, J.T., "Assessment of a Freshman Program: Introduction to Engineering at The Ohio State University, Academic Years 1998-2001", Proceedings of the 2001 American Society for Engineering Education Annual Conference, June 2001.

6. Vesilind, P. Aarne, "Mentoring Engineering students: Turning Pebbles into Diamonds", Engineering Education, pp. 407-411.

7. Smith, Karl A., Project Management and Teamwork, McGraw-Hill, NY, 2000.

8. Freuler, Richard J., John A. Merrill, Matthew S. Gates, Mary M. Lamont, and John T. Demel, “An Anonymous Electronic Journal System - Program Assessment Tool and Monday Morning Quarterback", submitted for review for the Proceedings of the 2002 American Society for Engineering Education Annual Conference, June 2002.

9. Buckley, Donald P., "In Pursuit of the Learning Paradigm”, EDCAUSE Review, Vol.37, No. 1, January/February 2002, pgs 29-38.

\section{JOHN T. DEMEL}

John T. Demel is a Professor of Engineering Graphics in the Department of Civil \& Environmental Engineering and Geodetic Science. Dr. Demel serves as the Faculty Coordinator for the Introduction to Engineering Program (IEP) and the Freshman Engineering Honors (FEH) program. Dr. Demel is a registered professional engineer in Texas and is involved in engineering education research. He is a co-author on four textbooks. He helped create and develop the FEH program. Dr. Demel earned his B.S.M.E. at the University of Nebraska-Lincoln in 1965 and his 
M.S. and Ph.D. degrees in Metallurgy from Iowa State University in 1968 and 1973 respectively. He taught at Savannah State College and Texas A\&M University prior to joining the faculty at Ohio State in 1980.

\section{ROBERT J. GUSTAFSON}

Robert J. Gustafson is a Professor of Food, Agricultural and Biological Engineering and Associate Dean for Academic Affairs and Student Services for the College of Engineering of The Ohio State University. Dr. Gustafson is a registered professional engineer and is actively engaged in development of first-year engineering programs and teaching improvement. Dr. Gustafson received B. S. and M. S. degrees in Agricultural Engineering from the University of Illinois in 1971 and 1972 and a Ph.D. in Agricultural Engineering from Michigan State University in1974.

\section{AUDEEN W. FENTIMAN}

Audeen W. Fentiman is an Associate Professor in the Department of Civil and Environmental Engineering and Geodetic Science. She also serves as the Chair for the Nuclear Engineering Program. Her research is in the areas of radioactive waste management, environmental engineering risk assessment, and engineering education. She holds B.S. and M.A. degrees in mathematics and M.S. and Ph.D. degrees in Nuclear Engineering, the later two from The Ohio State University

\section{RICHARD J. FREULER}

Richard J. Freuler is a Senior Researcher in the Aerospace Engineering and Aviation Department at The Ohio State University. Dr. Freuler is the Associate Director of the department's Aeronautical and Astronautical Research Laboratory and conducts scale model investigations of gas turbine installations for jet engine test cells and for marine and industrial applications of gas turbines. He is also the Faculty Coordinator for the OSU Freshman Engineering Honors (FEH) Program and teaches the three-quarter FEH engineering course sequence. Dr. Freuler received the B.S. and M.S. degrees in Aeronautical and Astronautical Engineering in 1974, a B.S. in Computer and Information Science in 1974, and a Ph.D. in Aeronautical and Astronautical Engineering in 1991 all from The Ohio State University.

\section{JOHN A. MERRILL}

Dr. Merrill received his Ph.D. in Instructional Design and Technology from The Ohio State University in 1985. He has an extensive background in public education, corporate training, and contract research. He is currently Program Manager for the Introduction to Engineering (IE) Program at The Ohio State University. His current responsibilities include management and assessment for the IE Program, including the use of web-based instruments. He also collaborates with the Associate Dean for Academic Affairs/Student Services, and with key faculty, in the establishment of outcome-based assessment processes. These activities were instrumental in helping the College of Engineering prepare for its accreditation visit under new criteria issued by the national Accreditation Board for Engineering and Technology (ABET). 